Bulletin d'études orientales

\title{
Biographies and select publications
}

\section{OpenEdition}

\section{Journals}

Electronic version

URL: http://journals.openedition.org/beo/161

DOI: $10.4000 /$ beo. 161

ISBN: 978-2-35159-318-9

ISSN: 2077-4079

\section{Publisher}

Presses de l'Institut français du Proche-Orient

\section{Printed version}

Date of publication: 1 March 2008

Number of pages: 101-104

ISBN: 978-2-35159-038-4

ISSN: 0253-1623

\section{Electronic reference}

"Biographies and select publications », Bulletin d'études orientales [Online], Supplément LVII | Mars 2008, Online since 13 November 2009, connection on 23 April 2019. URL : http:// journals.openedition.org/beo/161 ; DOI : 10.4000/beo.161 


\section{BIOGRAPHIES AND SELECT PUBLICATIONS}

\section{CEDRIC DEVAIS}

Cédric Devais, a doctoral student at the Sorbonne, is completing his doctoral dissertation, "La Terre de Suète, a Lordship of the Jerusalem Kingdom", under the direction of Michel Balard. He has received numerous scholarships for his research in Jordan from IFPO in Amman and has recently directed IFPO's Shawbak Hinterland Survey, an archaeological and architectural project. He is now working for the university of Culture and Communication in Paris

\section{BENJAMIN MICHAUDEL}

Benjamin Michaudel is a doctor in Art History and Archaeology of the University of Paris. His thesis, entitled "Ayyubid and Mamluk Forfications on the Syrian Coast at the end of 12th to the Early 14th Centuries", has been funded by IFPO in Damascus. Trained as a traditional historian, Mr. Michaudel has gradually turned to the study of Islamic military architecture in the East. He wrote his Master's thesis on the citadel of Shayzar and his DEA of Arabic Studies on the fortress of Sahyun/Qal'at Salah al-Din, two sites characteristic of Crusader and Islamic fortifications in Syria during the Crusades. While completing these degrees, he studied Arabic literature and dialects and, since 1997, has participated in several architectural surveys and stratigraphic excavations in Syria and Egypt.

\section{Publications}

— «Le château de Saône (Sahyûn, Qal'at Salâh al-Dîn) et ses défenses 》, Archéologie Islamique 11 (2001): 201-206.

— «Les organes de défense de l'enceinte ayyoubide du Caire » (Collectif), Annales Islamologiques 36 (2002): 287-337.

— «Les refortifications ayyoubides et mameloukes en Syrie du Nord (fin XIIe- début XIVe siècles) », dans La Fortification au temps des Croisades, ed. N. Faucherre, J. Mesqui, et N. Proteau. (Presses Universitaires de Rennes, 2004) : 179-188.

— «Le Crac des Chevaliers, quintessence de l'architecture militaire mamelouk », Annales Islamologiques (2004) (en cours de publication). 
— « The Development of Islamic Military Architecture through Ayyubid and Mamluk Reconquest of Frankish Syria », Actes du Colloque International d'Alep (2004-2005) (en cours de publication).

\section{ANDREW PETERSEN}

Andrew Petersen is currently lecturer at the University of Wales. He has written extensively on Islamic-period architecture in the Levant for the last fifteen years through his associations with the British School of Archaeology in Jerusalem, for which he directed medieval and Ottoman surveys for four years, and the Council for British Research in the Levant. His monograph on the hajj forts of Jordan will be published shortly by Oxford University Press.

\section{Publications}

— «Early Ottoman Forts on the Darb al-Hajj », Levant 21 (1989): 97-119.

— « Two Forts on the Medieval Hajj Route in Jordan », Annual of the Department of Antiquities of Jordan 35 (1991): 347-360.

- A Gazetteer of Buildings in Muslim Palestine. (Oxford, 2001).

— « Guardians of the Pilgrim Wells: Damascus to Aqaba », (co-authored with David L. Kennedy), Saudi Aramco World 55.1 (2004): 12-19.

- The Archaeology of Towns in Muslim Palestine. BAR International Series 1381, Archaeopress (Oxford 2005).

\section{DENISE AIGLE}

Denise Aigle is a specialist in the anthropology of religion and a world authority on the Mongols. She is affiliated with the Sorbonne, where she teaches, and has a research chair at CNRS. At the time of this conference, she was on research leave from the CNRS, directing a number of research projects at IFPO in Damascus. Dr. Aigle is interested in the writing of history and in contacts between cultures and world religions (namely Christianity, Islam, and Shamanism) and has published extensively on these themes.

\section{Publications}

\section{Ouvrages}

- L'Iran face à la domination mongole, études réunies et présentées, ed. D. Aigle (Paris-Téhéran, 1997).

- Figures mythiques de l'Orient musulmane, ed. D. Aigle (Revue du Monde Musulman et de la Méditerranée, 89-90, 2000).

— Le Fârs sous la domination mongole (XIII $-X I V^{e}$ s.). Politique et fiscalité (Paris, 2005).

- Bar Hebraeus, les Mongols et les Mamelouks. Traduction du dernier chapitre de sa chronique syriaque, accompagnée d'un commentaire historique (Lyon: Sources chrétiennes en collaboration avec G. Bohas, D. Gonnet et P. Lavenant). En préparation. 


\section{Articles}

— «Le mythe créateur d'histoire », dans Figures mythiques de l'Orient musulman, sous la direction de D. Aigle, Revue du Monde Musulman et de la Méditerranée, 89-90, 2000, p. 7-38.

— «Figures mythiques et histoire. Réinterprétations et contrastes entre Orient et Occident », dans Figures mythiques de l'Orient musulman, sous la direction de D. Aigle, Revue du Monde Musulman et de la Méditerranée, 89-90, 2000, p. 39-71.

— « Les transformations d'un mythe d'origine : l'exemple de Gengis Khan et de Tamerlan », dans Figures mythiques de l'Orient musulman, sous la direction de D. Aigle, Revue du Monde Musulman et de la Méditerranée, 89-90, 2000, p. 151-168.

— « Le 'grand yasa' de Gengis-khan, l'empire, la culture mongole et la sharí'a », Journal of the Economic and Social History of the Orient 47.1 (2004): 31-79.

— « Loi mongole vs loi islamique. Entre mythe et réalité », Annales Histoire, Sciences Sociales 5/6 (2005): $25-59$.

— «Les inscriptions de Baybars dans le Bilâd al-Shâm. Une expression de la légitimité du pouvoir », Studia Islamica 98 (2005): sous presse.

— «Bar Hebraeus et son public, à travers ses chroniques en arabe et en syriaque », Le Muséon, vol. 118.1-2 (2005): sous presse.

— « Le Prêtre Jean et le processus d'intégration des Mongols dans la conscience de la chrétienté occidentale », dans Le Prêtre Jean et l'Orientalisme, sous la direction de M. Tardieu, Leuven, Peeters, Collection Res Orientales (2005) : sous presse.

— « La question du Prêtre Jean dans les lettres d'Eljigidei et d'Abaqa. La politique pro-chrétienne des Ilkhan », dans Le Prêtre Jean et l'Orientalisme, sous la direction de M. Tardieu, Leuven, Peeters, Collection Res Orientales (2005) : sous presse.

— «L'occupation de Damas par Ghazan-khan en 1300 et les fatwâ-s anti-mongole d'Ibn Taymiyya », $B E O$ (2006): sous presse.

\section{BETHANY WALKER}

Bethany Walker is Associate Professor of Middle East History at Grand Valley State University in Michigan, where she teaches courses on medieval Middle Eastern history, Islam, and historical archaeology. She has been working in Jordan since 1998, when she joined the staff of the Tall Hisban excavations, part of the larger Madaba Plains Project. In addition to co-directing the Hisban project, she is Director of the Northern Jordan Survey. In addition to her archaeological fieldwork, Dr. Walker actively pursues a research agenda on Mamluk-period rural administration and agriculture, which is based on archival work in Cairo and Amman.

\section{Publications}

- Mamluk Administration of Transjordan: Recent Findings from Tall Hisban, al- 'Usur al-Wusta 13.2 (October, 2001): 29-33. 
— The Islamic Qusur of Tall Hisban: Preliminary Report on the 1998 and 2001 Seasons, Annual of the Department of Antiquities of Jordan 47 (2003): 443-471. (cowritten with Dystein S. LaBianca).

- Mamluk Investment in Southern Bilad al-Sham in the Fourteenth Century: The Case of Hisban, Journal of Near Eastern Studies 62.3 (2003): 241-261.

- Southern Syria in the Islamic Period: Political Periphery or Nexus?, in One Hundred Years of American Archaeology in the Levant: Proceedings of the American Schools of Oriental Research Centennial Celebration, Washington, DC, April 2000, ed. Doug Clark and Victor Matthews (Boston, 2003). Pp. 385-409.

— Mamluk Investment in the Transjordan: A 'Boom and Bust' Economy, Mamluk Studies Review 8.2 (2004): 119-147.

— The Northern Jordan Survey 2003: Agriculture in Late Islamic Malka and Hubras Villages: A Preliminary Report on the First Season, Bulletin of the American Schools of Oriental Research 339 (2005):1-44.

— Transformation of the Agricultural Economy of Late Mamluk Jordan, Mamluk Studies Review 10.2 (2006), in print.

- Rural Sufism as Channels of Charity in Nineteenth-Century Jordan, in Interpreting Relief and Welfare Activities in the Middle East: 1800-2005”, ed. Nefissa Naguib and Inger Marie Okkenhaug (forthcoming).

— Life on the Mamluk Frontier: Transjordan, 1250-1517 A.D. (Chicago, University of Chicago Middle East Documentation Center's Monograph Series, forthcoming). 